\title{
A Tale of Two States: Analyzing the State of Higher Education in Kerala and Karnataka
}

\author{
Arsh Rakesh Arora ${ }^{*} \quad$ Richa Gupta ${ }^{2}$ \\ 1.Faculty of Social Science, Charles University Prague, Czech Republic \\ 2.University of Social Sciences and Humanities, GGS Indraprastha University New Delhi, India \\ *E-mail of the corresponding author:27587055@fsv.cuni.cz
}

\begin{abstract}
In India, over 32 crore active learners have been affected by the closure of educational institutions across the country. There are a lot of obstacles such as accessibility, pedagogy and curriculum, infrastructure, and capabilities that can affect the transformation process. However, there is a positive side to digital learning such as increased efficiency, and scope of mass scale-up of operations. Every state in India faces unique challenges and a single policy representing the entire country's higher education system is unviable. The authors attempt to analyze the state of higher education in the state of Kerala and Karnataka based on four parameters, namely, accessibility, quality, privatization, and digital infrastructure. The last parameter being prime and obvious because pandemic is the inflection point for e-learning and digital infrastructure plays an important role. The research was conducted through an in-detailed literature review of research papers, policy documents, news articles, and government reports.
\end{abstract}

Keywords: higher education, quality, digital literacy, digital, e-learning

DOI: $10.7176 / \mathrm{JEP} / 12-10-01$

Publication date: April $30^{\text {th }} 2021$

\section{Introduction}

In India, over 32 crore active learners have been affected by the closure of educational institutions across the country. When classroom learning is hampered, universities switch to online remote learning. Although the transition was quickly adopted by most universities and colleges, it still has a long way to go. There are a lot of obstacles such as accessibility, pedagogy and curriculum, infrastructure, and capabilities that can affect the transformation process. However, there is a positive side to digital learning such as increased efficiency, and scope of mass scale-up of operations. To promote online learning Ministry of Human Resource and Development (MHRD) has come up with various initiatives. One such initiative is SWAYAM Prabha, an online education resource for students but lack of interaction with teachers, and assessment and evaluation problems lead to an important demarcation between online learning and e-learning.

Every state in India faces unique challenges and a single policy representing the entire country's higher education system is unviable. Therefore, each state must be assessed separately to identify the gaps and comfort points of the state's adoption of e-learning in the higher education system. In this policy brief, the author will focus on state-level policies for higher education and digital literacy in Kerala.

\subsection{Kerala}

The higher education system in Kerala is regulated by the Kerala University Act and Kerala Education Rules 1959. Currently, the sector is governed by multiple authorities such as the Higher Education Council, Department of Education, Directorate of College Education, Department of Technical Education, and universities. According to Kerala's economic review published in 2016, there are 14 universities and three deemed universities functioning in the State.

The district-wise spread of arts and science colleges gives a clear picture of the physical infrastructure. There are 63 colleges in the northern region and 89 colleges in central and southern districts. Out of 213 colleges in total, 153 are private un-aided and the rest are under the government. The number of students enrolled in arts and science colleges is 2.7 lakhs out of which 71 percent are girls. The most preferred degree among students is BA followed by B.Sc., then B.Com. However, in the transition from undergraduate to postgraduate studies, there is a significant drop in enrolment. For a case, the number of students for MA degree falls to 12000 from 96000 in BA degree.

For engineering, there are 171 self-financed colleges, 9 government colleges, and three private aided colleges. In Kerala, engineering colleges are skewedly located, 35 colleges in the north and going down through the state, the number of colleges increases to 72 and 96. Students enrolled in engineering colleges are over five thousand at the undergraduate level and 1500 at the postgraduate level. The Gross Enrolment Ratio according to 2018-19 All India Survey on Higher Education is 37 among general category, 25 and 23 among SC and ST population.

A review of the above statistics shows that higher education in Kerala is in a fairly satisfactory condition. 
However, the district-wise statistics and comparison with other southern states give a picture of disparity. The academicians have raised a lot of issues in the higher education sphere in Kerala such as accessibility, equity, privatization, and quality of education.

\subsection{Karnataka}

Karnataka has one of the most highly educated populations in India. The state has the largest number of schools and educational institutions, nearly half of which are managed by the government. The higher education system in Karnataka comprises degree colleges, technical and vocational colleges, universities, institutions, deemed to be universities, and institutions of higher education having national importance. There are different types of colleges such as government colleges, privately managed colleges, private-aided colleges, University colleges, and professional colleges.

In Karnataka, higher education is governed by the Karnataka State Higher Education Council Act. The regulatory authorities in the state are Karnataka State Higher Education Council (KSHEC), Directorate of College, and Directorate of Technical Education. As of 2018, there are 28 state public universities, one central university, 16 state private universities, 11 deemed universities. In total there are 64 universities in the state. There are close to 4000 colleges in the state out of which 3020 are private colleges. In 2018-19 percentage of expenditure on higher education of the state, GDP is $2.25 \%$ and $20 \%$ of the total education expenditure. Gross Enrolment Ratio in 2018 is 28.8, among SC and ST population it is 21 and 19 respectively. GER among the male and female population is at par in general, SC and ST categories.

The following section will cover the specific parameters for the analysis of the state of higher education in two states viz. accessibility, quality, privatization, and digital infrastructure.

\section{Accessibility}

In Kerala, even though there is a vast network of higher education institutions, colleges per lakh eligible population are one of the lowest compared to other southern states of India. There are only 45 colleges per lakh population of 18-23 years age group leaving only Tamil Nadu behind. District-wise data shows that engineering colleges in northern districts such as Wayanad and Kasargod with higher populations are far less compared to other regions.

The 2011 census shows that most of the colleges in central and southern regions lie within 5-10 kilometers of a household whereas the colleges in northern regions lie beyond ten kilometers. An interesting data points higher education enrollment is approximately seven lakhs, the lowest in the state allowing us to conclude reasons for low enrolment such as afflux of students to other states for better job opportunities and better instruction quality.

According to the All India Survey on Higher Education (AISHE)-2019, college density is 53 per lakh eligible population in Karnataka as compared to the national average, 28. This number is higher when compared to its neighbor states. This has increased from 41 in 2011-12. Karnataka also has the highest number of students coming from foreign countries i.e. over ten thousand in 2017-18. Even the number of private unaided colleges is the highest among southern states in India. Kerala - 1032 Tamil Nadu - 2131 Andhra Pradesh - 2223 Telangana - 1700. There are over 15 lakh students enrolled in the undergraduate course and over 2 lakh students at the postgraduate level.

Going down to the district level, there are 30 districts in Karnataka and district-wise analysis of higher education categorizes them into three major categories - lagging, strongest, and districts that require special attention. Yadgir, Raichur, Chamrajnagar, Koppal, Haveri - these districts are categorized as the weakest districts in the state. In the above districts, there is usually low enrolment among backward classes and women, low institutional density, some are drought-prone areas, one of the districts have a low Gender Parity Index. Dakshina Kannada, Mysuru, Bangalore Urban, Udupi, Dharwad are categorized as the strongest five districts in the higher education sector in the state. These districts have high institutional density, higher enrolment, gender parity, etc. Districts that require special needs are Haveri, Bangalore Rural, Bellary, Kodagu, and Chitradurga.

The urban-rural differentiation in terms of access to higher education can be exemplified by understanding the differences between Bengaluru Urban and Bengaluru Rural. In general, there are a higher number of state public universities, private universities, and polytechnic colleges in urban Bengaluru than in rural Bengaluru. Additionally, GER among SC and ST students is far behind in rural Bengaluru than its urban counterpart. As a result of such unbalanced development, higher education in rural Bengaluru is riddled with lower performance, higher gender parity, and low enrolment ratio. It is clear that rural Bengaluru is in a special need category and urban Bengaluru is in the progressive category in the higher education sector.

\section{Quality}

The Annual Survey on Education Report 2018 highlights the fact that poor quality of school education has a ripple effect on higher education. Kerala's record highest literacy rate in the country, a laudable school system is 
responsible for this achievement. However, the higher education system did not manage to replicate the model of school education. Quality of education can be ascertained if it is providing returns to students in the form of rightly matched employment or further study opportunity and making law-abiding informed citizens.

Around twenty-five percent of the undergraduate students from seven colleges in Kerala preferred to study out of the state for higher studies concluding that the higher education system in Kerala is not sufficient to meet the needs of its students. The 2016 economic review of Kerala highlights the fact that the number of job seekers in Kerala is rising with the expanding labor demand for manual jobs. Another possible reason for students from Kerala to move out is the mismatch between the courses available and courses demanded by the students.

Literature focusing on the issue of the quality of higher education is limited, however, one of the researchers attempts to link quality with the privatization of education. The research concludes in self-financing colleges the percentage of students passing in an academic year was as low as 35 percent whereas the percentage increased to 65 percent in government colleges affiliated to the same university.

Karnataka Higher Education Perspective Plan lays importance on enhancing the quality of education on various parameters such as improving institutional infrastructure, capacity building of teachers, quality of teaching and learning, better assessment, and accreditation of colleges. Some academicians in the state are of the view that accreditation by NAAC is a basic parameter to assess the quality of universities and colleges in Karnataka. There has been an attempt to make the Internal Quality Assurance Cell (IQAC) work better. One significant achievement is the development of a data bank. Many colleges have been successful in this direction.

Among all states in the country, Karnataka received the largest migrants for education with 1,80,000 students. Even though Karnataka's population is only 5\% of the Indian population, its share in higher education is close to $15 \%$. A paper that studied the factors responsible for such a high influx of migrant students to Karnataka concludes that prospects of a better career and job/entrepreneurship prospects compel students to migrate.

\section{Privatizing Higher Education}

After the formation of the state in 1956, most of the colleges were government-run and private aided till the 1990s. From 1990 to 2007-08 the proportion of self-financing colleges in the field of medical and engineering increased to 80-90 percent, further rising to 93 percent in 2017.

Privatization of higher education has raised issues such as quality of learning, accessibility, and affordability. One of the authors noted that the performance of self-financing colleges affiliated with Kerala University is lower than that of government-run affiliated colleges recording pass percentage of students.

Privatization has given a major thrust to professional and technical education in the state. The economic review of 2016 has laid out the priority for the 12th five-year plan to promote public-private partnership in the field of technical education, research and innovation institutions. In this effort, the government has come into agreement with many multinational companies for establishing centers for research and training at the university campuses.

It is noted that privatization is necessary for professional and technical education to make the learning according to market needs thus increasing the chances of employability. However, researchers and educators have highlighted various issues arising because of commercialization such as financial barriers leading to inaccessibility, inequity, and deteriorating quality which may continue to persist with lack of government intervention.

There has been a noticeable increase in self-finance colleges in the state, which in turn has raised quality issues. Most of these colleges are outside the purview of UGC Grants and are run purely on user fees and philanthropic contributions. Therefore, the tendency is to start only such relevant market-driven courses with an unexplainable fee structure. The capitation lobby is very active in teacher education, management, engineering, and paramedical colleges.

\section{Digital Infrastructure}

\subsection{Kerala}

KFON (Kerala Fibre Optic Network)

KFON forms an essential part of the Kerala government's ambitious plan to provide Internet connection to below poverty line (BPL) families, government offices, hospitals, and schools. About 12 lakhs of BPL families will be given a free Internet connection. KFON is a highly scalable network infrastructure that provides on-demand, affordable broadband connectivity of up to $100 \mathrm{Mbps}$ for organizations and households. The network connects the state administration with all urban and rural areas to address the digital divide.

- As of 2016, the state has a vast Optical Fiber Communication network of which BSNL had contributed majorly covering $20,000 \mathrm{~km}$, followed by Reliance $(8,500 \mathrm{~km})$, and other major players being Airtel, Vodafone, Idea, and Tata (nearly 3,225 km put together).

- Currently, the State has nationally the highest mobile penetration of about 32 million connections, the 
highest internet penetration covering about 20 percent of households through broadband and another 15 percent through mobile. (Economic Review, 2016)

- Internet subscribers in Kerala as of 31st March 2016 are 14.6 million. In urban areas, the number is 9.02 million, and in rural areas -5.57 million. Internet subscriber per 100 population (2016) is 41.38 .

- In 2015 the government launched a project to install public Wi-Fi at ten thousand schools but there is no implementation assessment of the program. Currently, there are 2000 public Wi-Fi hotspots in the state.

5.1.1 Digital Literacy

There is a great digital divide persisting in the country especially between urban and rural areas. In India, only 10 percent of households have uninterrupted internet and a computer. In 2015 only 18 percent of people belonging to the age group 14-29 years in rural areas were able to operate computers as compared to 48 percent in urban areas.

The impact assessment report of the National Digital Literacy Mission published in 2015 provides a summary of the state of digital literacy in Kerala.

- As of 2013-14, 81\% males and 74\% females belonging to the $14-29$ years of age group know how to operate a computer.

- As of 2013-14, only 30\% of households have computers with an internet facility.

- According to Digital Literacy Index, Kerala is a moderate performer.

There are various programs launched by the state government since the 9th five-year plan in the ICT sector to bridge the digital divide and promote e-literacy in the state. Kerala is the only state in the country where at least one person in $49 \%$ of families is computer literate. There are 78.35 lakh households in the state, almost 39.17 lakh have at least one family member who knows how to operate a computer. $97 \%$ of villages in the state have an internet café, even as the national average is $17 \%$.

5.1.2 Digital Education

Akshaya project was launched in 2002 in Kerala to bridge the digital divide by providing training to at least one member of a family to be e-literate. In the initial stage, basic training was provided to the selected candidates to familiarize themselves with the basics and scope of IT. It was the largest rural e-literacy training project worldwide organized ever and concluded by transforming 32.8 lakh citizens benefitting from the initiative.

Akshaya Centres have emerged as the finest network of effective Common Service Centres (CSC) to deliver citizen-centric services. The project uses various models of delivery such as G2C, G2B as well as B2C services. Presently, around 2,650 Akshaya e-centres are spread across Kerala with at least 2 centers in each Panchayats. By bringing ICT to all segments of people Akshaya acts as a vehicle for improved quality of life, accessibility to information, transparency in governance, and overall socio-economic growth.

KITE (Kerala Infrastructure and Technology for Education) was established by the government to foster, promote and implement the modernization of educational institutions in the State of Kerala. The spectrum of KITE includes Information \& Communication Technology, Capacity Building, Content Development, Connectivity, e-Learning, Satellite-based education, Support and Maintenance mechanism, e-Governance, or other related activities.

In 2020, the scope of KITE is further expanded to the Higher Education sector also including Arts \& Science, Engineering colleges, and Universities, to fuel ICT support in learning and teaching activities.

The project has so far reached out to more than 39 lakh students spread across 12,600 schools of Kerala with a high level of digital literacy.

Kerala IT Policy 2017 - The main agenda of the policy is to establish Kerala as a leading IT destination and generate direct and indirect employment opportunities in the IT sector. It necessitates building necessary technological infrastructure, enhances the necessary human capital required to both produce and use innovative technologies through education and skill-building. It also lays out the aim to make the state $100 \%$ e-literate and utilize ICT in all walks of life to ensure equitable and inclusive development of the society.

"I am also Digital" - In March 2020 Kerala government launched an ambitious program to bring 100 percent digital literacy to the state of Kerala. The e-literacy drive was launched by Kerala State IT Mission. The scheme is intended to run through people's participatory mode, wherein the trainers will be invited from the communities to impart training to people in their community. Educating people about using digital technology and cybersecurity will enhance the capacity of society.

\subsection{Karnataka}

A study was conducted in 2016 among school students in urban and rural areas across the state. The purpose of the paper was to examine the digital divide and various problems faced by the students in using the computer and to know the reasons for not using computers by rural and urban students. A total of almost 2600 sample population were selected from 64 rural and urban high schools of two districts of Karnataka state. The findings of the research reveal that various digital barriers are existing in the state. The study found that only $20.66 \%$ of 
rural students used the computer for various purposes while the number of students who came from the urban area (69.70 percent) used computers. The reason for less usage of computers is because of the non-availability of the computer in rural schools, the students are not able to use the computer.

There is a significant difference between rural and urban students concerning their familiarity with various applications of the computer. The majority of rural students used computers to play computer games whereas the majority of urban students used the computer for project works.

The most important findings were that the majority of rural and urban students faced electric power failure as one of the problems faced while using computers. And most of the rural students were mainly dependent on the computer available at schools since they do not have computer facilities at home.

5.2.1 Digital Literacy

The impact assessment report of the National Digital Literacy Mission published in 2015 provides a summary of the state of digital literacy in Karnataka. According to the report, as of $2013-14,41 \%$ of males and $30 \%$ of females belonging to the 14-29 years of age group knows how to operate a computer. Additionally, the report suggests that close to $20 \%$ of households have computers with an internet facility. According to the Digital Literacy Index, Karnataka is a moderate performer, with scope for improvement in rural areas.

5.2.2 Digital Education

Jananasangama - Smart Karnataka Education Yardstick (SMART-Key) - "Jananasangama” Smart Karnataka Education Yardstick is an initiative by the Government of Karnataka. It is a 100-point program that aims to remove the existing deficiencies in the system by adopting the technology. The objective of the program is improving access and quality of learning, reducing cost, making administration transparent, etc. The following are some of the targets which are intended to promote e-learning in higher education in the state:

- Establish smart class, tele-education, e-library.

- Integrating digital libraries and e-contents.

- Make e-content available to all students and staff in the state.

- Smart support for students

- Setting up multimedia recording studios for e-contents.

- Transforming the examination system.

As mentioned earlier there are 100 ICT-based initiatives ongoing in the higher education system in the state. These are related to all aspects such as assignments, online books, online exams, class, and curriculum, to list a few. E-content, E-library, integration of e-resources of all universities are the major digital initiatives to promote online learning in the state.

The presentation by Karnataka State Higher Education highlights the importance of ICT in solving critical issues existing in the higher education sector in Karnataka. The presentation mentions that E-Literacy for all levels, E-learning for teachers, students, and staff, E-content for UG level are already implemented Initiatives announced such as online admission process, E-Library resource, E-content for PG levels, online exams are yet to be implemented. According to Telecom Statistics Report - 2018, there are in total 30.16 million internet subscribers. 6.59 million in rural areas and 23.57 in urban areas.

5.2.3 Other Digital Initiatives

The government of Karnataka has taken various initiatives to ease the use of technology across all user cohorts. One major development has come in the form of deployment of Wi-Fi hotspots using NOFN backhaul of BSNL at 2150 Gram Panchayats across Karnataka. Wi-Fi Connectivity for all governments of Karnataka websites is limited to $100 \mathrm{Mb}$ /day for each GP's. In 2019, the government announced the setting up of $4000 \mathrm{WiFi}$ hotspots in the capital city in partnership with private companies. However, this was not the first time such a project was announced. Since 2014 many such projects have been launched but are never implemented.

Another initiative called 'CHETNA' aims to empower, mentor, and support girls through various activities including training sessions to use the laptop, as well as interactive sessions with leaders from various domains like science, technology.

During the lockdown as part of India's strategy to reduce the spread of the Coronavirus pandemic, the Karnataka Government launched an e-learning program, GetCETGo for students preparing for the Common Entrance Test (CET) and National Eligibility-cum-Entrance Test (NEET), to make it easier for students to prepare for entrance exams.

\section{Conclusion}

The research leads us to a paradoxical conclusion. Firstly, the state of higher education in terms of quality, and accessibility was not up to the mark in both states, and with the advent of a pandemic, the situation must have worsened. Secondly, the digital infrastructure in the state is largely financed and built by the government but in higher education, the role of government is shrinking and market forces have more influence. It leads us to an interesting crossroads of government, private market forces, and higher education institutions where all three players have different agendas and priorities. Therefore, it will need a more analytical approach to understand 
and analyze how these stakeholders will interact in the time of pandemic to tackle the old challenges and embrace new ones.

\section{References}

1. Chopra, D. (2020). Kerala to launch digital literacy drive "I am also digital". Retrieved from India Today: https://www.indiatoday.in/education-today/news/story/kerala-to-launch-digital-literacy-drive-divd1653861-2020-03-09

2. Council for Social Development . (2017). Impact Assessment of the National Digital Literacy Mission. New Delhi: Council for Social Development http://www.csdindia.org/pdfs/Project-reports/Digital-Literacy-Report-2017.pdf

3. Department of Electronics and Information Technology . (2017). Kerala IT Policy 2017. Thiruvananthapuram: Department of Electronics and Information Technology . http://www.keralaindustry.org/images/pdf/policy/Kerala-IT-Policy-2017-1.pdf

4. Department of Telecommunications . (2018). Telecom Statistics India-2018 . Delhi: Economics Research Unit https://dot.gov.in/sites/default/files/statistical\%20Bulletin-2018.pdf

5. Education Department (Higher). (2016, March 9). ICT initiatives in Higher Education, Government of Karnataka. Retrieved from Slide Share: https:/www.slideshare.net/eGovMagazine/ict-initiatives-in-highereducation-department-gok

6. ET Government. (2020, April 21). Covid-19 crisis: Karnataka pushes for e-learning, launches GetCETGo for NEET, CET students. Retrieved from Economic Times: https://government.economictimes.indiatimes.com/news/digital-india/covid-19-crisis-karnataka-pushes-fore-learning-launches-getcetgo-for-neet-cet-students/75263619

7. Government of Kerala. (n.d.). Kerala Infrastructure and Technology for Education. Retrieved from Kerala Infrastructure and Technology for Education: https://kite.kerala.gov.in/KITE/index.php/welcome/infra

8. Government of Kerala. (n.d.). Kerala IT. Retrieved from Infrastructure: http:/www.keralait.org/

9. Government of Kerala. (n.d.). Kerala State IT Mission. Retrieved from Infrastructure: https://itmission.kerala.gov.in/digital_infrastructure

10. Jandhyala, T. (2015). How is Kerala doing in Higher Education?. Kochi: Council for Social Development. https://www.researchgate.net/publication/281391768_How is_Kerala_doing_in_Higher_Education

11. Jegadeeswari, S., \& Raghavendran , V. (2019). Quality of Higher Education in the State of Karnataka (India). International Journal of Recent Technology and Engineering, 4959-4961. https://www.ijrte.org/wp-content/uploads/papers/v8i4/C6712098319.pdf

12. Karnataka State Higher Education Council. (2018). KARNATAKA STATE HIGHER EDUCATION PERSPECTIVE PLAN. Bangalore: Karnataka State Higher Education Council.

13. Karnataka State Higher Education Council. (n.d.). gnanasangama. Retrieved from Karnataka State Higher Education Council: http://www.gnanasangama.karnataka.gov.in/Index.aspx

14. Kerala State Higher Education Council. (n.d.). Online Study Materials for Programmes of Universities of Kerala. Retrieved from Kerala State Higher Education Council: http://167.172.224.184/kshec_learning/

15. Kumar, N. A., \& George, K. (2009, October 10). Kerala's Education System: From Inclusion to Exclusion? Economic \& Political Weekly, pp. https://www.epw.in/journal/2009/41-42/special-articles/keralas-education-system-inclusion-exclusion.html

16. Ministry of Human Resource and Development . (2018). All India Survey on Higher Education. New Delhi: Ministry of Human Resource and Development https://mhrd.gov.in/sites/upload_files/mhrd/files/statistics-new/AISHE\%20Final\%20Report\%20201819.pdf

17. Ministry of Human and Resource Development. (2018). All India Survey on Higher Education. Delhi: Government of India. https://mhrd.gov.in/sites/upload_files/mhrd/files/statistics-new/AISHE\%20Final\%20Report\%20201819.pdf

18. Nair, P. (2015, January 19). 1 in 49\% Kerala families computer literate. Retrieved from Times of India: https://timesofindia.indiatimes.com/india/1-in-49-Kerala-families-computerliterate/articleshow/45935329.cms

19. Narahari, A. M. (n.d.). Higher Education in Karnataka: Status, Perspectives and Challenges. Retrieved from Association of Manglore College Teachers: http://www.amuct.org/images/stories/articles/001.pdf

20. Rao, S., \& Andini, V. (2019, August). Modeling Student Migration to Karnataka for Higher Education using Partial Least Square Structural Equation Model. Higher Education Quaterly, 135-152. https://doi.org/10.1111/hequ.12173 
21. Sampath , B. K., \& Kumara, S. S. (2018). The digital divide in India: use and non-use of ICT. World Journal of Science, Technology and Sustainable Development, 156-168. https://doi.org/10.1108/WJSTSD-07-2017-0021

22. State Planning Board. (2018). Economic Review 2017. Thiruvananthapuram: Government of Kerala. http://spb.kerala.gov.in/ER2017/web e/index.php

23. Tripathi, H. (2019). Higher Education in Kerala: Development, Equity and Issue of Access. South Asia Research, 1-19. https://journals.sagepub.com/doi/abs/10.1177/0262728019872054

24. State Planning Board. (2017). Economic Review 2016. Thiruvananthapuram: Government of Kerala. https://kerala.gov.in/documents/10180/ad430667-ade5-4c62-8cb8-a89d27d396f1 